\title{
Pengenalan Pola Daun Untuk Membedakan Tanaman Padi dan Gulma Menggunakan Metode Principal Components Analysis (PCA) dan Extreme Learning Machine
}

\author{
Ahmad Izzuddin," M. Rizal Wahyudi \\ Universitas Panca Marga, J. Yos Sudarso No. 107, Probolinggo, Indonesia \\ *izzuddin76@gmail.com
}

Kata Kunci :

Padi

Gulma

Pengenalan Pola

Principal Components

Analysis

Extreme Learning Machine

\section{ABSTRAK}

Perkembangan ilmu pengetahuan serta pesatnya teknologi memberikan banyak manfaat bagi manusia dalam menjalankan aktifitasnya. Pemanfaatan ilmu pengetahuan dan teknologi tersebut di berbagai bidang termasuk di bidang pertanian. Pengembangan potensi pertanian suatu daerah dapat dioptimalkan melalui perkembangan ilmu pengetahuan dan teknologi itu sendiri. Salah satunya dengan pengenalan pola citra digital. Pengenalan pola bertujuan menentukan kelompok atau kategori pola berdasarkan ciriciri yang dimiliki oleh pola tersebut. Dengan kata lain, pengenalan pola membedakan suatu objek dengan objek lain. Dengan menggunakan metode ektraksi ciri Principal Component Analysis dan metode klasifikasi Extreme Learning Machine penulis melakukan penelitian untuk membedakan tanaman padi dan tanaman gulma. Implementasi PCA dan ELM mampu membedakan tanaman gulma dengan padi (Oryza sativa L) dalam hal ini gulma yang digunakan adalah jawan (Echinochloa cruss-galli) dan kremah (Alternanthera sessilis). Berdasarkan hasil pengujian yang dilakukan 8 kali running dengan merubah jumlah hidden neuron diperoleh nilai akurasi paling tinggi sebesar 91,67 \% dengan menggunakan 10, 15, $30,35,40$ hidden neuron, sedangkan untuk nilai akurasi paling rendah sebesar 58\% dengan jumlah hidden neuron 5. Waktu yang dibutuhkan ELM untuk melakukan pelatihan dan pengujian sangat singkat 0.374 detik dan 0.500 detik pengukuran dilakukan dimulai dari running program sampai proses running program selesai.

The development of science and technology rapidly benefits many people in running their activities. Utilization of science and technology in various fields including agriculture. The development of a regional agricultural potential can be optimized through the development of science and technology itself. One of them is the introduction of digital image patterns.The pattern recognition aims to determine a pattern or group of patterns based on the characteristics inherent in the pattern. In other words, pattern recognition distinguishes an object from another object. Using the extraction method of Principal Component Analysis and the Extreme 
Learning Machine classification method, the authors conduct a research to differentiate rice plants and weeds. PCA and ELM impediment can distinguish weeds with rice (Oryza sativa L) in this case weeds are used (Echinochloa cruss-galli) and cremate (Alternanthera sessilis). Based on the results of the test performed 8 times running by changing the number of hidden neurons obtained the highest accuracy value of $91.67 \%$ using 10, 15, 30, 35, 40 hidden neurons, while for the lowest accuracy value of $58 \%$ with the number of hidden neurons 5. The ELM time required to perform very short training and testing of 0.374 seconds and 0.500 seconds measurements is done starting from the running program until the process of running the program is completed.

\section{Pendahuluan}

Indonesia merupakan negara agraris dan sebagian besar penduduknya bermata pencaharian di bidang pertanian. Salah satu tanaman budidaya di bidang pertanian adalah tanaman padi. Hampir setiap petani di Indonesia membudidayakan tanaman ini, karena nasi berasal dari tanaman padi yang merupakan makanan pokok di Indonesia. Gulma merupakan tanaman pengganggu yang merugikan tanaman budidaya dengan menghambat pertumbuhan tanaman budidaya. Gulma memiliki banyak sepesies dan memiliki sifat-sifat yang berbeda-beda. Pengenalan spesies gulma merupakan langkah awal yang menentukan keberhasilan pengendalian gulma.

Tanaman gulma merupakan salah satu tanaman pengganggu tanaman padi. Gulma merugikan tanaman padi dengan cara berkompetisi kebutuhan cahaya, $\mathrm{CO} 2$, air, hara, dan aleopati, dengan mengeluarkan zat beracun yang menghambat tanaman padi. Selama ini proses pengendalian yang dilakukan oleh para petani dengan cara dicabut.

Berdasarkan latar belakang masalah diatas, penulis mengemukakan gagasan membuat sistem pengenalan pola daun membedakan tanaman padi dan tanaman gulma secara otomatis oleh suatu komputer dengan judul "Pengenalan Pola Daun untuk Membedakan Tanaman Padi dan Tanaman Gulma menggunakan Metode Principal Component Analysis dan Extreme Learning Machine".Penulisan teks diawali pada bagian ini, dengan menuliskan dalam bentuk paragrah. Artikel ditulis dalam satu kolom. Untuk menjaga mutu penampilan jurnal, setiap artikel yang dikirim harus sesuai dengan template ini. Tidak perlu menyertakan nomor halaman pada paper anda, karena pemberian halaman dilakukan oleh redaksi terkait dengan proses layout jurnal. Hal-hal yang perlu diperhatikan. Ukuran kertas yang digunakan adalah A4 (21 cm x 29,7 cm). File petunjuk penulisan ini telah menggunakan aturan dan format penulisan baku yang disarankan, sehingga dapat langsung dijadikan template.

\section{Rumusan Masalah}

Adapun rumusan masalah dalam penelitian ini adalah Bagaimana membangun sebuah pengenalan pola daun untuk membedakan tanaman padi dan gulma menggunakan metode Principal Component Analysis dan Extreme Learning Machine. 


\section{Tujuan Penelitian}

Berdasarkan latar belakang, maka tujuan dari penelitian ini adalah untuk membangun sebuah pengenalan pola daun untuk membedakan tanaman padi dan gulma menggunakan metode Principal Component Analysis dan Extreme Learning Machine.

\section{Gambar}

Batasan masalah penelitian ini adalah :

Objek penelitian ini adalah daun tanaman padi dan tanaman gulma yaitu Gulma Jawan (Echinochloa cruss-galli) dan Kremah (Alternanthera sessilis) Jumlah sampel data 120 terbagi 96 data latih dan 24 data uji

Metode yang digunakan Principal Component Analysis dan Extreme Learning Machine.

\section{Manfaat Penelitian}

Hasil penelitian ini diharapkan memberikan manfaat bagi pihak-pihak yang bergerak dalam bidang pertanian untuk dapat mengenali padi dan gulma yang dapat dijadikan dasar dalam mengembangkan teknologi untuk pengendalian gulma.

\subsection{Pengolahan Citra Digital}

Pengolahan citra adalah pemrosesan citra, khususnya menggunakan komputer menjadi citra yang kualitasnya lebih baik dan sesuai dengan keinginan pemakai. Pengolahan citra bertujuan memperbaiki kualitas citra agar mudah diinterpretasi oleh manusia atau mesin komputer $(\mathrm{Mu}$ nir, 2004). Pengolahan citra merupakan disiplin ilmu yang mempelajari hal-hal yang berkaitan dengan perbaikan kualitas gambar (peningkatan kontras, transformasi warna, restorasi citra), transformasi gambar (rotasi, translasi, skala, transformasi geometrik), melakukan pemilihan ciri citra (feature images) yang optimal untuk tujuan analisis, melakukan proses penarikan informasi atau deskripsi objek atau pengenalan objek yang terkandung pada citra, melakukan kompresi atau reduksi data untuk tujuan penyimpanan data, transmisi data, dan waktu proses data. Input dari pengolahan citra adalah citra, sedangkan output-nya adalah citra hasil pengolahan (Sutoyo, 2009). Teknik-teknik pengolahan citra mentransformasikan citra ke citra yang lain. Jadi masukannya adalah citra dan keluarannya juga citra, namun citra keluaran atau hasil mempunyai kualitas lebih baik dari pada citra masukan (Sutoyo, 2009).

\subsection{Pengenalan Pola}

Pengenalan pola merupakan serangkaian proses yang dilakukan secara serial, mulai dari proses deteksi atau segmentasi, proses ekstraksi dan pengukuran kemiripan atau proses pengenalan. Deteksi merupakan proses untuk memperoleh lokasi objek secara tepat yang akan dikenali. Proses segmentasi atau deteksi ini terkadang juga didapat diabaikan, ketika objek yang sudah terdeteksi secara tepat lokasinya, misalnya pengenalan wajah yang menggunakan data wajah ORL. Data citra ORL yang disediakan dapat langsung diekstraksi dan diikuti dengan pengukuran kemiripan tanpa melalui proses deteksi terlebih dahulu (Muntasar, 2015). Untuk mengenali pola suatu objek, ada dua pendeketan yang sering digunakan yaitu metode yang menggunakan teori statistik, dan yang kedua menggunakan teori bahasa formal auto mata atau 
dikenal dengan nama pendekatan pengenal secara sintaktik. Model pengenalan sintaktik relatif lebih sulit dibandingkan dengan pendekatan pertama (Muntasar, 2015).

\subsection{Ekstraksi Ciri Principal Component Analysis (PCA)}

Principal Component Analysis atau sering disebut dengan PCA merupakan teknik linier reduksi menggunakan teori-teori sederhana dari statistik ( Turk,1991). Teori statistik sederhana tersebut adalah varian, standart deviasi, zero mean, kovarian dan persamaan karakteristik dengan ditemukannya PCA, telah membawa perubahan yang sangat besar pada ekstraksi fitur yang berbasis "appearence" (Muntasar, 2015). Ide dasar PCA adalah untuk melakukan pengurangan dimensi dari parameter yang saling berkorelasi. Jika PCA digunakan dalam penelitian yang menggunakan ci tra sebagai domainnya, biasanya proses PCA diawali dengan melakukan transformasi matrik dua dimensi menjadi satu dimesi untuk setiap objek data pelatihan maupun data uji coba, oleh sebab itu PCA yang semacam ini disebut juga dengan One Dimensional Principal Component Analysis atau disebut dengan 1D/PCA (Muntasar,2015).

PCA mengurangi dimensi dari sekumpulan data pelatihan yang sebagian besar variabelnya saling terkait dan tetap mempertahankan sebanyak mungkin variasi yang terdapat pada data set sebagian data pelatihan (A.M Martinez dan A.C.Kak, 2001). Komponen utama dari data pelatihan merupakan hasil proyeksi eigen vektor yang berkorelasi dengan eigen value yang terurut secara menurun. Semakin kecil nilai eigen value, maka semakin tidak dominan ciri yang dihasilkan oleh proyeksi terhadap eigen vektor (M.turk and A.Pentlan,D 1991). Dan sebaliknya semakin besar nilai eigen value, maka semakin dominan ciri yang dihasilkan oleh proyeksi terhadap eigen vektor (Muntasar,2015).

PCA akan bekerja secara optimal ketika jumlah dataset $m$ jauh lebih kecil dengan dimensi masing-masing data pelatihan $\mathrm{n}(\mathrm{m}<<\mathrm{n})$, dimana $\mathrm{n}$ merupakan hasil transformasi dua dimensi menjadi satu dimensi atau $\mathrm{n}=\mathrm{h} * \mathrm{w}$. Dalam hal ini $\mathrm{h}$ merupakan tinggi citra sedangkan $\mathrm{w}$ merepresentasikan lebar dari citra. Jika $n>m$, maka reduksi yang dihasilkan justru lebih besar dari pada jumlah data pelatihan. Ini artinya reduksi dimensi tidak dapat bekerja secara optimal, ketika jumlah data pelatihan yang digunakan lebih besar dari dimensi citra $(m>n)$ (Muntasar, 2015).

\subsection{Klasifikasi Extreme Learning Machine}

Jaringan Saraf Tiruan (JST) adalah model komputasi untuk pemrosesan informasi dan identifikasi pola yang dikembangkan berdasarkan permodelan sistem saraf biologis dari otak manusia (Zhang, 2004). Model JST pertama kali diperkenalkan pada tahun 1943 oleh McCulloch dan Pitts (Fu, 1994). JST merupakan jaringan dengan banyak unit komputasi yang disebut dengan neuron atau sel yang saling berhubungan dan terorganisasi dalam layer-layer (Zhang, 2004). Setiap neuron yang terdapat pada lapisan JST bertugas untuk melakukan pengolahan informasi dengan memproses input yang diterima menjadi output. Setiap neuron saling berhubungan dan memiliki bobot masing-masing yang akan mengalikan sinyal yang ditransmisikan. Terdapat fungsi aktivasi pada setiap neuron yang akan menentukan besarnya keluaran. Susunan dari JST sering ditentukan berdasarkan jumlah layer dan banyaknya neuron pada setiap layer. Tipe dari layer tersebut adalah:

Input layer : Neuron pada lapisan ini disebut sebagai unit masukan yang diberikan untuk 
pemrosesan jaringan.

Hidden layer : Neuron pada lapisan ini disebut sebagai unit tersembunyi, yang tidak dapat diamati karena tersembunyi.

Output layer: Neuron pada lapisan ini disebut sebagai unit keluaran yang menghasilkan nilai yang ditetapkan sesuai perhitungan (Fu, 1994).

ELM adalah jaringan saraf tiruan feedforward single layer atau yang biasanya disingkat dengan SLFNs. ELM pertama kali dikenalkan oleh Huang, Zhu dan Siew (Huang, 2006). Terdapat banyak jenis dari jaringan saraf tiruan feedforward yang populer yang terdiri dari single atau multi hidden layer seperti pembelajaran basis gradient, contohnya metode backpropagation untuk multi-layer feedforward neural network. Namun, pembelajarannya sangat lambat dari yang diharapkan hal ini disebabkan karena semua parameter yang diberikan harus ditentukan secara manual dan diperlukan iterative tuning pada setiap parameternya. Pada metode ELM setiap pameter diberikan secara acak tanpa iterative tuning sehingga menghasilkan learning speed yang cepat (Huang, 2011). Metode ELM memiliki struktur yang hampir sama dengan SLFNs, namun memiliki model komputasi yang berbeda. Secara matematis, ELM dimodelkan seperti berikut :

Diketahui :

Himpunan latih $\mathrm{X}$ dan target sampel $\mathrm{T}$, dimana $\mathrm{T}=\{(x i, t i) \mid x i, t i \in R m, \mathrm{i}=1, \cdots, \mathrm{N}\}$; Jumlah fitur dari sampel disimbolkan dengan $n$ Fungsi aktifasi disimbolkan dengan g(x)Jumlah node pada hidden layer disimbolkan dengan $\mathrm{L}$

Nilai vektor bobot input (W) dan hidden node bias (b) yang ditentukan secara acak.

Dari penjelasan sebelumnya maka perhitungan matematisnya adalah sebagai berikut: Hitung keluaran dari lapisan tersembunyi

$\mathrm{H}=\mathrm{H}(\mathrm{g}(\mathrm{w} \cdot \mathrm{x}+\mathrm{b})$

Hitung bobot output $(\beta) \beta=H$ † T

Hitung nilai output $Y$

$\mathrm{Y}=H \dashv \beta$ dimana :

$H \dagger$ adalah generalisasi invers Moore-Penrose dari output hidden layer (matrik H). Aturan dari Moore- Penrose yaitu : $\mathrm{H}$ H† $\mathrm{H}=\mathrm{H}$ (Murdoko dansaparudin, 2015)

\section{Diagram Alir Sistem}

Dibawah ini merupakan alur dari proses pengenalan pola daun untuk membedakan tanaman padi menggunakan metode PCA dan ELM. 


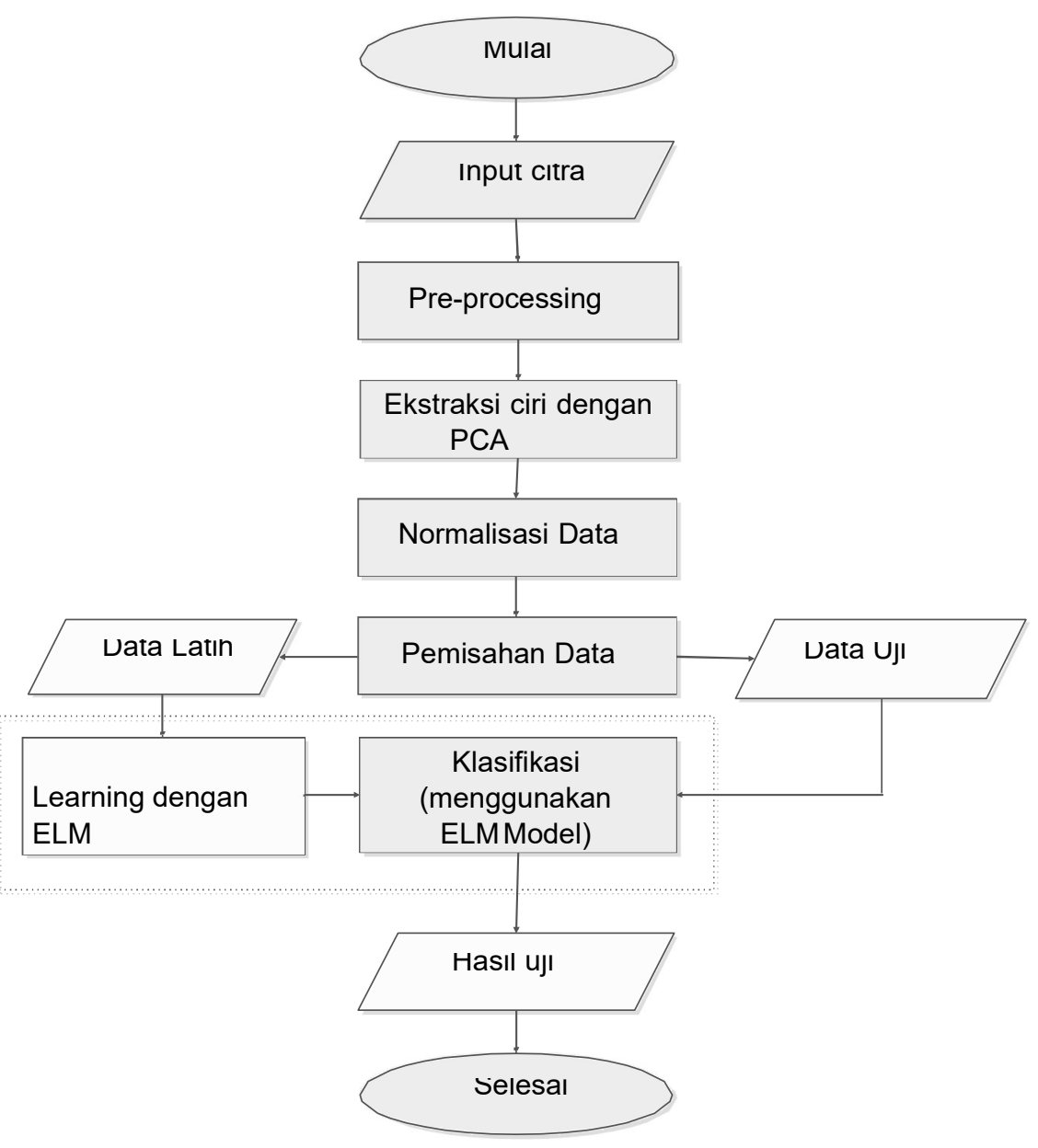

Gambar 1 Diagram Proses Pengenalan Padi dan Gulma

\section{Hasil Penelitian dan Pembahasan}

Pada bagian ini akan dijelaskan hal yang terkait dengan hasil penelitian proses pengenalan pola daun menggunakan metode ekstraski ciri PCA dan hasil pengujian klasifikasi ELM.

Data Citra

Jumlah seluruh sampel data 75 yang terbagi 25 sampel tanaman PADI , 25 sampel JAWAN dan $25 \mathrm{KREMAH}$. Pengambilan gambar digunakan kamera Canon A2500. Hasil citra berukuran 3456 x 4608 pixel dengan resolusi 180 dpi dengan ekstensi JPG. Sampel citra yang berukuran 3456 x 4608 pixel diubah menjadi 100x75 pixel menggunakan photoshop.

Tabel 1 - Contoh sebuah tabel

\begin{tabular}{c} 
Padi \\
\hline+2 Kremah
\end{tabular}



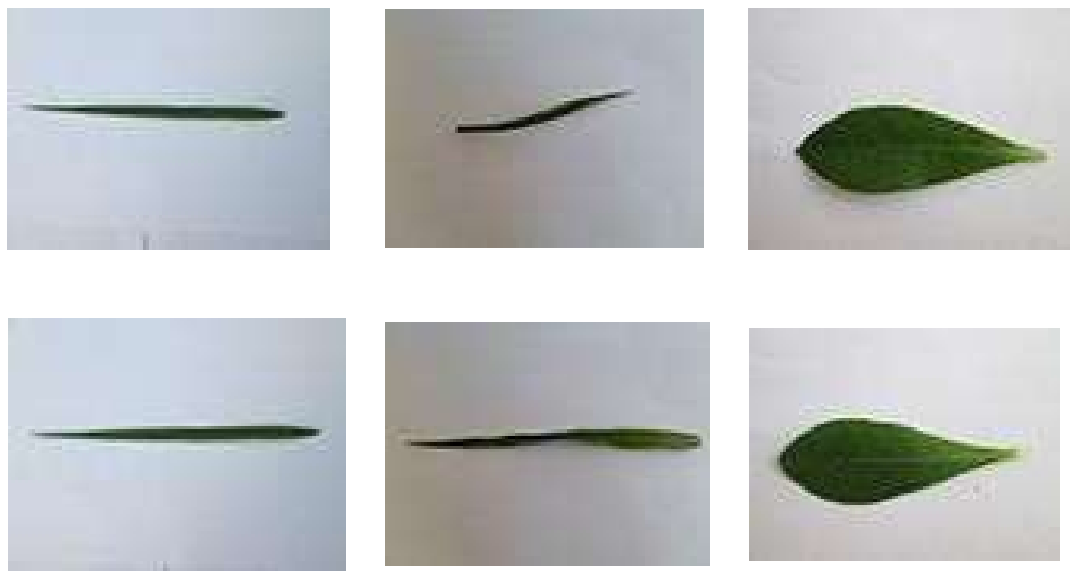

\section{Implementasi Sistem}

Implementasi sistem yang dilakukan pada penelitian ini terdiri dari dua tahapan utama yaitu tahapan pelatihan dan tahapan pengujian dimana masing- masing tahap memiliki nilai yang saling berhubungan .

\section{Input Data}

Membaca citra merupakan tahap awal yang dilakukan dalam dalam proses pengenalan pola. Citra padi dan gulma dengan ukuran $100 \times 75$ pixel yang nantinya akan digunakan sebagai data latih dan data uji.
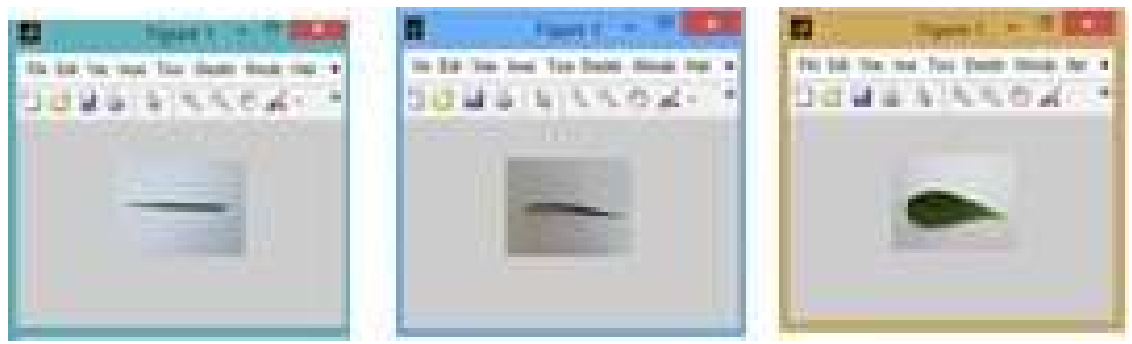

Gambar 2 Citra Padi dan Gulma

\section{Preprocessing}

Pada proses preprocessing dilakukan pemisahan background dengan obyek untuk mendapatkan citra biner. Proses ini disebut dengan proses thresholding.

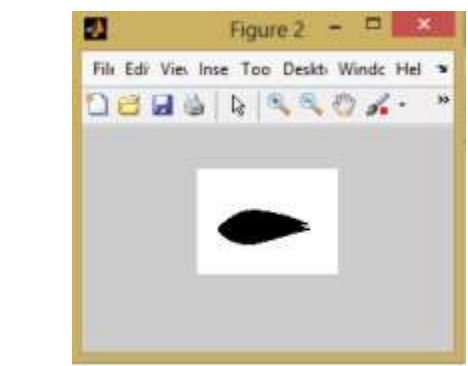

Gambar 3 Hasil Citra Tresholding

\section{Ekstraksi ciri menggunakan Principal Component Analysis (PCA)}

Setelah melakukan preprocessing, peneliti melakukan proses ekstraksi ciri, dimana pada tahap ini akan diambil nilai ciri-ciri pada setiap citra. Pada penelitian ini peneliti menggunakan 
metode PCA.

\section{Normalisasi Data}

Data hasil ekstraksi ciri PCA yang akan dimasukkan ke dalam ELM dinormalisasi sehingga mempunyai nilai dengan rentang tertentu. Hal ini diperlukan karena fungsi aktivasi yang digunakan akan menghasilkan output dengan rentang data $[-1,1]$.

\section{Pembagian Data Latih dan Uji}

Pembagian data latih dan data uji. Peneliti membagi data latih sebesar 60 dan data uji 15. Proses pembagian data latih dan data uji digunakan sebagai input pada ELM.

\section{Klasifikasi menggunakan Extreme Learning Machine (ELM)}

Setelah proses pembagian data latih dan data uji maka proses selanjutnya adalah pelatihan.

Peneliti melakukan pengujian dengan menggunakan jumlah hidden nueron 5-40 dengan jumlah 15 data uji.. Berikut hasil pengujian yang dilakukan oleh peneliti :

Pengujian pertama dengan 5 Hidden Neuron

Tabel 2 Pengujian dengan 5 Hidden Neuron

\begin{tabular}{|l|l|l|l|l|l|l|l|l|l|l|l|l|l|l|l|l|l|l|l|l|l|l|l|}
\hline \multicolumn{1}{|c|}{ PADI } & \multicolumn{1}{|c|}{ JAWAN } & \multicolumn{1}{|c|}{ KREMAH } & \multicolumn{3}{|c|}{} \\
\hline \hline 1 & 2 & 3 & 4 & 5 & 6 & 7 & 8 & 9 & 10 & 11 & 12 & 13 & 14 & 15 & 16 & 17 & 18 & 19 & 20 & 21 & 22 & 23 & 24 \\
\hline 1 & 3 & 1 & 2 & 1 & 1 & 1 & 2 & 2 & 3 & 2 & 2 & 2 & 3 & 3 & 3 & 3 & 3 & 3 & 3 & 3 & 3 & 3 & 3 \\
\hline
\end{tabular}

Keterangan :

Padi memiliki label 1 Jawan memiliki label 2 Kremah memiliki label 3

Untuk Menghitung tingkat akurasi adalah :

Akurasi $=($ Jumlah data benar $) /($ Jumlah data uji $) \times 100 \%$

$=14 / 24 \times 100 \%$

$=58 \%$

Pengujian kedua dengan 10 Hidden Neuron

Tabel 3 Pengujian dengan 10 Hidden Neuron

\begin{tabular}{|l|l|l|l|l|l|l|l|l|l|l|l|l|l|l|l|l|l|l|l|l|l|l|l|}
\hline \multicolumn{10}{|c|}{ PADI } & \multicolumn{10}{c|}{ JAWAN } & \multicolumn{10}{|c|}{ KREMAH } & \multicolumn{1}{|c|}{} \\
\hline \hline 1 & 2 & 3 & 4 & 5 & 6 & 7 & 8 & 9 & 10 & 11 & 12 & 13 & 14 & 15 & 16 & 17 & 18 & 19 & 20 & 21 & 22 & 23 & 24 \\
\hline 1 & 1 & & 1 & 1 & 1 & 1 & 1 & 2 & 2 & 2 & 2 & 2 & 2 & 2 & 2 & 3 & 3 & 3 & 3 & 3 & 2 & 2 & 3 \\
\hline
\end{tabular}

Keterangan :

Padi memiliki label 1 Jawan memiliki label 2 Kremah memiliki label 3

Untuk Menghitung tingkat akurasi adalah :

Akurasi $=($ Jumlah data benar $) /($ Jumlah data uji $) \times 100 \%$

$=22 / 24 \times 100 \%$

$=91,67 \%$

Pengujian ketiga dengan 15 Hidden Neuron 
Tabel 4 Pengujian dengan 15 Hidden Neuron

\begin{tabular}{|l|l|l|l|l|l|l|l|l|l|l|l|l|l|l|l|l|l|l|l|l|l|l|l|}
\hline \multicolumn{10}{|c|}{ PADI } & \multicolumn{10}{|c|}{ NAWAN } \\
\hline 1 & 2 & 3 & 4 & 5 & 6 & 7 & 8 & 9 & 10 & 11 & 12 & 13 & 14 & 15 & 16 & 17 & 18 & 19 & 20 & 21 & 22 & 23 & 24 \\
\hline 1 & 1 & 1 & 1 & 1 & 1 & 1 & 1 & 2 & 2 & 2 & 2 & 1 & 2 & 2 & 2 & 3 & 2 & 2 & 3 & 3 & 3 & 3 & 2 \\
\hline
\end{tabular}

Keterangan :

Padi memiliki label 1 Jawan memiliki label 2 Kremah memiliki label 3

Untuk Menghitung tingkat akurasi adalah :

Akurasi $=($ Jumlah data benar $) /($ Jumlah data uji $) \times 100 \%$

$=20 / 24 \times 100 \%$

$=83 \%$

Pengujian keempat dengan 20 Hidden Neuron

Tabel 5 Pengujian dengan 20 Hidden Neuron

\begin{tabular}{|l|l|l|l|l|l|l|l|l|l|l|l|l|l|l|l|l|l|l|l|l|l|l|l|}
\hline \multicolumn{10}{|c|}{ PADI } & \multicolumn{10}{|c|}{ IAWAN } \\
\hline 1 & 2 & 3 & 4 & 5 & 6 & 7 & 8 & 9 & 10 & 11 & 12 & 13 & 14 & 15 & 16 & 17 & 18 & 19 & 20 & 21 & 22 & 23 & 24 \\
\hline 1 & 1 & 1 & 1 & 1 & 1 & 1 & 1 & 2 & 2 & 2 & 2 & 2 & 1 & 2 & 2 & 3 & 3 & 3 & 3 & 3 & 2 & 3 & 3 \\
\hline
\end{tabular}

Keterangan :

Padi memiliki label 1 Jawan memiliki label 2 Kremah memiliki label 3

Untuk Menghitung tingkat akurasi adalah :

Akurasi $=($ Jumlah data benar $) /($ Jumlah data uji $) \times 100 \%$

$=22 / 24 \times 100 \%$

$=91,67 \%$

Pengujian kelima dengan 25 hidden neuron

Tabel 6 Pengujian dengan 25 Hidden Neuron

\begin{tabular}{|l|l|l|l|l|l|l|l|l|l|l|l|l|l|l|l|l|l|l|l|l|l|l|l|}
\hline \multicolumn{10}{|c|}{ IAWI } & \multicolumn{10}{c|}{ KREMAH } \\
\hline 1 & 2 & 3 & 4 & 5 & 6 & 7 & 8 & 9 & 10 & 11 & 12 & 13 & 14 & 15 & 16 & 17 & 18 & 19 & 20 & 21 & 22 & 23 & 24 \\
\hline 1 & 1 & 1 & 1 & 1 & 1 & 1 & 1 & 2 & 2 & 2 & 3 & 2 & 1 & 2 & 2 & 3 & 3 & 3 & 3 & 3 & 3 & 3 & 3 \\
\hline
\end{tabular}

Keterangan :

Padi memiliki label Jawan memiliki label 2 Kremah memiliki label 3

Untuk Menghitung tingkat akurasi adalah :

Akurasi $=($ Jumlah data benar $) /($ Jumlah data uji $) \times 100 \%$

$=22 / 24 \times 100 \%$

$=91,67 \%$

Pengujian keenam dengan 30 hidden neuron 
Tabel 7 Pengujian dengan 30 hidden neuron

\begin{tabular}{|l|l|l|l|l|l|l|l|l|l|l|l|l|l|l|l|l|l|l|l|l|l|l|l|}
\hline \multicolumn{10}{|c|}{ PADI } & \multicolumn{10}{|c|}{ IAWAN } \\
\hline 1 & 2 & 3 & 4 & 5 & 6 & 7 & 8 & 9 & 10 & 11 & 12 & 13 & 14 & 15 & 16 & 17 & 18 & 19 & 20 & 21 & 22 & 23 & 24 \\
\hline 1 & 1 & 1 & 1 & 1 & 1 & 1 & 1 & 2 & 2 & 2 & 1 & 2 & 2 & 2 & 2 & 3 & 3 & 3 & 3 & 3 & 2 & 3 & 3 \\
\hline
\end{tabular}

Keterangan :

Padi memiliki label 1 Jawan memiliki label 2 Kremah memiliki label 3

Untuk Menghitung tingkat akurasi adalah :

Akurasi $=($ Jumlah data benar $) /($ Jumlah data uji $) \times 100 \%$

$=22 / 24 \times 100 \%$

$=91,67 \%$

Pengujian ketujuh dengan 35 hidden neuron

Tabel 8 Pengujian dengan 35 Hidden Neuron

\begin{tabular}{|l|l|l|l|l|l|l|l|l|l|l|l|l|l|l|l|l|l|l|l|l|l|l|l|}
\hline \multicolumn{10}{|c|}{ PADI } & \multicolumn{10}{|c|}{ KAWEMAN } \\
\hline 1 & 2 & 3 & 4 & 5 & 6 & 7 & 8 & 9 & 10 & 11 & 12 & 13 & 14 & 15 & 16 & 17 & 18 & 19 & 20 & 21 & 22 & 23 & 24 \\
\hline 1 & 1 & 1 & 1 & 1 & 1 & 1 & 1 & 2 & 2 & 2 & 1 & 2 & 2 & 2 & 2 & 3 & 3 & 3 & 3 & 3 & 2 & 3 & 3 \\
\hline
\end{tabular}

Keterangan :

Padi memiliki label 1 Jawan memiliki label 2 Kremah memiliki label 3

Untuk Menghitung tingkat akurasi adalah :

Akurasi $=($ Jumlah data benar $) /($ Jumlah data uji $) \times 100 \%$

$=22 / 24 \times 100 \%$

$=91,67 \%$

Pengujian kedelapan dengan 40 hidden neuron

Tabel 9 Pengujian dengan 40 Hidden Neuron

\begin{tabular}{|l|l|l|l|l|l|l|l|l|l|l|l|l|l|l|l|l|l|l|l|l|l|l|l|}
\hline \multicolumn{10}{|c|}{ PADI } & \multicolumn{10}{|c|}{ IAWAN } \\
\hline 1 & 2 & 3 & 4 & 5 & 6 & 7 & 8 & 9 & 10 & 11 & 12 & 13 & 14 & 15 & 16 & 17 & 18 & 19 & 20 & 21 & 22 & 23 & 24 \\
\hline 1 & 1 & 1 & 1 & 1 & 1 & 1 & 1 & 2 & 2 & 2 & 3 & 2 & 2 & 2 & 2 & 3 & 3 & 3 & 3 & 3 & 1 & 3 & 3 \\
\hline
\end{tabular}

Keterangan :

Padi memiliki label 1 Jawan memiliki label 2 Kremah memiliki label 3

Untuk Menghitung tingkat akurasi adalah :

Akurasi $=($ Jumlah data benar $) /($ Jumlah data uji $) \times 100 \%$

$=22 / 24 \times 100 \%$

$=91,67 \%$ 


\section{Kesimpulan}

Kesimpulan yang didapat dari hasil uji coba perancangan dan pengimplementasian metode Principal Component Analysis (PCA) dan Extreme Learning Machine (ELM) untuk pengenalan pola daun padi dan gulma dapat diambil bahwa Impelementasi PCA dan ELM mampu membedakan tanaman gulma dengan padi (Oryza sativa L) dalam hal ini gulma yang digunakan adalah jawan (Echinochloa cruss-galli) dan kremah (Alternanthera sessilis). Berdasarkan hasil pengujian yang dilakukan sebanyak 8 kali dengan merubah jumlah hidden neuron berturut-turut dari 10, 15, 30, 35, 40 diperoleh nilai akurasi paling tinggi sebesar 91,67 $\%$, sedangkan untuk nilai akurasi paling rendah sebesar 58\% dengan jumlah hidden neuron 5 . Waktu yang dibutuhkan ELM untuk melakukan pelatihan dan pengujian sangat singkat 0.374 detik dan 0.500 detiks pengukuran dilakukan dimulai dari running program sampai proses running program selesai.

\section{Daftar Pustaka}

Fu, L. M. 1994. "Neural Networks In Computer Intelligence". Tata McGraw-Hill Education. Grist, D. H. 1965. Rice. 4th edition. Longman Group Limited. London. 548 p.

Huang, G. B., Zhu, Q. Y., \& Siew, C. K. 2006. "Extreme Learning Machine: Theory and Applications". Neurocomputing, 70 (1), 489-501. IRRI. 1985. Gulma. PT Bhratara Karya Aksara. Jakarta.

Mubyarto. 1995. Pengantar Ekonomi Pertanian. LP3ES. Jakarta. Muntasar, Arif. 2015. Pengenalan Pola. Yogjakarta. Graha Ilmu.

Ramza Harry., dan dewanto. 2007. Teknik Pemrograman Menggunakan MATLAB. Grasindo. Siregar, H. 1981. Budidaya Tanaman Padi di Indonesia. PT Sastra Hudaya. Jakarta.

Smith, R. J. 1983. Weeds of major economic importance in rice and yield losses due to weed competition. p 19-35. In: Weed Control in Rice. InternationalRice Research Institute. Los Banos.

Suryana, A. 2005. Pembangunan Pertanian Berkelanjutan Andalan Pembangunan Nasional.

Sutoyo, T. 2009. Fieldbus : Teori Pengolahan Citra Digital URL : repository.usu.ac.id/bitstream/123456789/29885/2/Reference.pdf Zhang, G. P. (Ed.). 2004. "Neural Networks In Business Forecasting”. IGI Global. 